\title{
From prophylaxis to atomic cocktail: Circulation of radioiodine
}

\author{
María Jesús Santesmases \\ Departamento de Ciencia, Tecnología y Sociedad Instituto de Filosofía, CSIC, Madrid. \\ mariaj.santesmases@cchs.csic.es
}

Dynamis

[0211-9536] 2009; 29: 337-363
Fecha de recepción: 22 de febrero de 2008

Fecha de aceptación: 22 de julio de 2008

SUMMARY: 1.- Introduction. 2.-Goiter and iodine in the 1920s and 1930s. 3.-After the war. 4.- «Good news» and new tools: radioiodine knowledge and practices. 5.- Requesting procedures: a US-Spain Agreement in 1949. 6.-Circulating radioiodine. 7.-A laboratory of experimental endocrinology. 8.-Conclusions: for a history of iodine.

ABSTRACT: This paper is a history of iodine. To trace the trajectory of this element, goiter is used as a guideline for the articulation of a historical account, as a representation of thyroid disorders and of the spaces of knowledge and practices related to iodine. lodine's journey from goiter treatment and prophylaxis in the late interwar period took on a new course after WWII by including the element's radioactive isotopes. I intend to show how the introduction of radioiodine contributed to stabilize the epistemic role of iodine, in both its non-radioactive and radioactive form, in thyroid gland studies and in the treatment of its disorders.

PALABRAS CLAVE: Yodo radioactivo, endocrinología, España, Junta de Energía Nuclear, Gregorio Marañón, bocio, relaciones diplomáticas hispanoestadounidenses.

KEY WORDS: Radioiodine, endocrinology, Spain, Junta de Energía Nuclear, Gregorio Marañón, goitre, US-Spanish diplomatic relations.

\section{Introduction $\left(^{*}\right)$}

In June 1922, a trip made by King Alfonso XIII of Spain with doctors Varela and Gregorio Marañón to Las Hurdes drew public attention to the affliction of goiter in that region, one of the poorest and most isolated mountain regions in southwest Spain. The king visited places where very

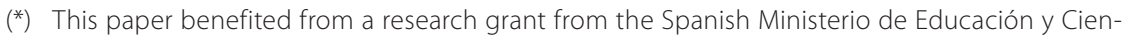
cia (HUM2006-04939/FISO). 
poor families lived in insalubrious huts, who ate an extremely poor diet and gave birth to cretins and unhealthy babies. It was the first time a king had traveled to such a place, and the experience led him to comment that «it is terrible, I can not bear to see any more» ${ }^{1}$.

This was the second time influential clinician Gregorio Marañón had visited Las Hurdes. By that time Marañón, like other physicians in Spain, was aware of the relationship between the high prevalence of goiter and cretinism in the region of Las Hurdes and iodine deficiency in the diet. The visits made by these doctors turned the Las Hurdes problem into one involving both medical and social issues, and which until then had been related to race degeneration. However, it was not completely clear to them whether the administration of iodine to these people would be a good treatment for goiter at a time when the use of iodine treatment was still at the pilot stage ${ }^{2}$.

Iodine was an element that was involved in the creation of endocrinology as a discipline and in the development of studies of thyroid hormones. By the 1920s iodine had started being used as treatment for goiter, and was also considered for its prophylaxis. From the late 1930s onwards, the introduction of its radioisotopes-radioidine involved negotiations of meanings and concepts of health and endocrinology 3 .

1. Granjel, Mercedes. Las Hurdes, el país de la leyenda. Lleida: Milenio; 2001. Marañón, Gregorio. Viaje a Las Hurdes. Madrid: El País Aguilar-Fundación Gregorio Marañón; 1993.

2. Granjel, n. 1, p. 149-168. Marañón, Gregorio. El bocio en España y sus condiciones patogénicas, Anales de la Academia de Medicina Quirúrgica Española 1927-1928. Escobar del Rey, Francisco; Morreale de Escobar, Gabriela. Marañón y el tiroides. In: Revisión de la obra médica de Gregorio Marañón. Madrid: Fundación Santander Central Hispano-Fundación Aventis; 2003, p. 23-101.

3. Lenoir, Timothy; Hays, Margarite. The Manhattan Project of Biomedicine. In: Sloan, Phillip R. ed. Controlling our destinies. Historical, philosophical, ethical and theological perspectives on the Human Genome Project. Notre Dame, Indiana: University of Notre Dame Press; 2000, p. 29-62. Creager, Angela N.H. Tracing the politics of changing postwar research practices: the export of «American» radioisotopes to European biologists. Studies in History and Philosophy of Biological and Biomedical Sciences. 2002; 33: 367-388. Creager, Angela N.H. The industrialization of radioisotopes by the US Atomic Energy Commission. In: Grandin, Karl; Woormbs, Nina, eds. The Science-Industry Nexus: History, Policy, Implications. Sagamore Beach, MA: Science History Publications; 2004. p. 143-167. Creager, Angela N.H. Nuclear energy in the service of biomedicine: the US Atomic Energy Commission's Radioisotope Program, 1946-1950. Journal of the History of Biology, 2006; 39: 649-684. Krige, John. The politics of phosphorus-32: A cold war fable based on facts. Historical Studies on the Physical and Biological Sciences, 2005; 36: 71-91. On the British side see Kraft, Alison. Between Medicine and Industry: Medical Physics and the Rise of Radioisotope 1945-1965. Contemporary Brit- 
Dynamis 2009; 29: 337-363

After WWII, the role of radioiodine in the origins of nuclear medicine was one of the most influential outcomes of the Radioisotopes Distribution Program of the US Atomic Energy Commission and its associated funding provision. Embedded in this program for isotope distribution, iodine, in its radioactive forms, from 1946 onwards resulted in a meaningful tool originating from atomic energy that contributed to health and medicine ${ }^{4}$.

This paper deals with the history of iodine. To trace its trajectory, goiter is used here as a guideline for the articulation of a historical account, as a representation of thyroid disorders and of the spaces of knowledge and practices related to iodine. Iodine's journey from goiter treatment and prophylaxis in the late interwar period took on a new course after WWII by including the element's radioactive isotopes. I intend to show how the introduction of radioiodine contributed to stabilize the epistemic role of iodine, in both its non-radioactive and radioactive form, in thyroid gland studies and in the treatment of its disorders.

I start by presenting a brief account of the connections between goiter and iodine from the 1920s until WWII in Spain. I continue by examining the circulation of knowledge and practices from the early establishment of radioactive iodine in thyroid research. Taking the Spanish Civil War (1936-1939) as a breaking point, and one that also affected research agendas, I then revise medical reports from the 1940s on iodine related to goiter studies and treatment and introduce the work of a group in Granada that did research on the relationship between goiter and

ish History. 2006; 20: 1-35. See also Creager, Angela N.H; Santesmases, María J. Radiobiology in the Atomic Age: Changing research practices and policies in comparative perspective. Journal of the History of Biology, 2006; 39: 637-647. Menéndez, Alfredo. Átomos para la Paz y para la Medicina. La popularización de las aplicaciones médicas de la energía nuclear en España. Revista Española de Medicina Nuclear, 2007; 26: 385-399. And Santesmases, María J. Peace propaganda and biomedical experimentation: influential uses of radioisotopes in endocrinology and molecular genetics in Spain. Journal of the History of Biology. 2006; 39: 765-794. See also Creager article in this volume.

4. Creager, 2002, n. 3 and Creager, 2004, n. 3. Also Westwick, Peter J. Abraded from several corners: medical physics and biophysics at Berkeley. Historical Studies in the Physical Sciences. 1996; 28: 131-162; Kohler, Robert E. Partners in science: Foundations and natural scientists 19001945. Chicago: University of Chicago Press; 1991. Heilbron, John; Seidel, Robert W. Lawrence and his laboratory: A history of the Lawrence Berkeley laboratory. Berkeley: University of California Press; 1989. 
iodine deficiency in the same decade ${ }^{5}$. A revision of reports published in Spanish clinical journals on the uses of radioiodine is followed by an account of the earliest requests for radioisotopes by Spanish researchers and clinicians, which reveal the steps leading up to the signing of an agreement between the US and Spain to authorize radioisotope shipments in 1948. Shipments received in 1949 by medical researchers and the earliest reports of practices with radioiodine are presented as a further development in the introduction of radioiodine to research and clinical settings. Finally, research with radioactive iodine by two scientists after a postdoctoral period in Leiden (the Netherlands) in the mid-1950s are summarized in order to show how the incorporation of radioiodine was articulated around the activity of the thyroid gland by two influential experimental endocrinologists on their return to Madrid.

The fact that an agreement between Spain and the US regarding requests for and shipments of radioisotopes was signed in 1948, a time when the Spanish dictatorship was internationally isolated and therefore not participating in the international organisations being formed at the time, not only introduced Cold War diplomacy as an agent in the process of circulating atomic products after WWII but also introduced radioisotopes to the diplomatic deployments of that time ${ }^{6}$.

By helping to construct expert knowledge, the trajectory of iodine isotopes from the 1920s until the 1960s created spaces of authority for those Spanish clinicians and researchers involved. Both local people and ways of reshaping practices played a part. ${ }^{7}$ Adjusting historical accounts to materials, in this case stable and radioactive elements, may contribute to a further understanding of circulation itself by including instruments and tools as agents which travelled and reconstructed meanings in local settings.

5. Romero, Ana; Santesmases, María Jesús, eds. Cien años de política científica en España. Madrid: Fundación BBVA; 2008. Santesmases, M. J. Viajes y memoria: las ciencias en España antes y después de la Guerra Civil. Asclepio. 2007; 59 (2): 213-230.

6. Krige, John. Atoms for peace, scientific internationalism and scientific intelligence. Osiris. 2006; 21: 161-181.

7. de Chadarevian, Soraya; Strasser, Bruno. Molecular biology in postwar Europe: toward a global picture. Studies in History and Philosophy of Biological and Biomedical Sciences. 2002; 33: 361-365. 


\section{Goiter and iodine in the 1920s and 1930s}

Considered a disease for decades and associated to poverty and cretinism, endemic goiter remained a medical issue of public significance. The main feature of goiter is an enlargement of the human thyroid gland resulting in a prominent swelling at the front of the neck.

Experimental results obtained by US researcher David Marine during the 1910s on the relationship between iodine deficiency and goiter showed that the bigger the gland hyperplasia the lower the iodine concentration in it. Iodine treatment tests on patients affected by goiter produced successful results. Those results were considered the main evidence for the efficient use of iodine in the treatment of thyroid disorders. Beside anatomic signs, the measurement of the basal metabolic rate (assessed by measuring the patient's oxygen consumption, which was high in hyperthyroidism) was the only useful laboratory test of thyroid activity at that stage. During the 1920 s goiter began to be treated by intake of iodine salts ${ }^{8}$.

Data available on the connection between goiter and iodine deficiency led to the first International Conference on Goiter and Cretinism, held in Berne (Switzerland) in 1928. The conference was a forum for presenting results of pilot projects on iodization in order to promote an international consensus that could urge the adoption of the iodine prophylaxis of endemic goiter and cretinism. In both Switzerland and the US, iodization was adopted. However, in Spain isolated regions remained endemic to this affliction. Gregorio Marañón presented a report at the conference, in which he rejected iodine prophylaxis for Spain arguing that it was too specific a remedy for a condition he considered to need widespread measures to improve economic development in endemic regions ${ }^{9}$.

The memoirs of Spanish clinicians and historians of medicine identified Gregorio Marañón as a leading physician in the promotion of endocrinology, who also contributed to the promotion of medical research and further studies on the relationship between goiter and iodine ${ }^{10}$. His influence

\footnotetext{
8. Fragu, Philippe. Interactions physiologie-outils therapeutiques dans les constructions physiopathogiques de goitre exophtalmique. Revue d'Histoire des Sciences. 2000; 53: 107-132.

9. Marañón, Gregorio. Resumé de l'etat actuel du problem du goitre endemique en Espagne. In Schwitzer Kropfkommission. Bericht über die Internationale Krofpkonferenz in Bern 24-26 August 1927. Berne: Hans Huber, 1928. p. 389-401.

10. Lain Entralgo, Pedro. Gregorio Marañón. Madrid: Espasa Calpe; 1976.
} 
remained both clinical and public. At the Hospital General in Madrid, in the mid 1910s, Marañón had introduced organotherapy by using thyroid extracts for treatment in cases of hyperthyroidism, in opposition to the views of many of his colleagues at that time, both in Spanish clinical settings and abroad ${ }^{11}$. Marañón set up a department of Endocrinology at the Instituto de Patología Médica in Madrid in 1925 and in 1932 a chair of endocrinology for postgraduate studies was created at the University of Madrid Medical School, to which he himself was appointed chairman. Thyroid diseases featured among his main clinical interests in endocrinology 12 .

Endemic goiter was considered the main health problem in Las Hurdes region, although some others were detected as urgent, such as malaria, protection of infancy, and better hygiene in houses and huts. ${ }^{13}$ Marañón, Goyanes and some of their colleagues' socio-medical approaches brought about the need for widespread social measures to overcome the miserable situation. Las Hurdes was a terrible example of the inability of authorities and public concerns to successfully deal with the problems and needs of its inhabitants ${ }^{14}$.

After the King's visit, the Royal Committee for Las Hurdes (Real Patronato de las Hurdes, of which Marañón was a member) was created and Javier Vidal Jordana was appointed the physician in charge of local medical care. In 1924, Vidal Jordana proposed a general preventive measure for goiter consisting of the addition of «infinitesimal quantities» of potassium iodide to common salt (3mg of iodide for each kilogram of salt) and at schools he sought teachers' collaboration in giving 1 milligram of potassium iodide to every child every week. By 1924 Vidal Jordana was seeking to determine the optimal doses ${ }^{15}$.

More than three years later, in 1927, Vidal Jordana published a report in which he stressed the difficulties for a proper diagnosis, as many people

11. Sengoopta, Chandak. The most secret quintessence of life: sex, glands, and hormones, 18501950. Chicago: University of Chicago Press, 2006.

12. Escobar; Morreale, n. 2. Glick, Thomas F. On the diffusion of a new speciality: Marañón and the «Crisis» of endocrinology in Spain. Journal of the History of Biology. 1979; 9: 287-300.

13. Rodríguez-Ocaña, Esteban; Bellester, Rosa, Perdiguero, Enrique; Medina, Rosa; Molero, José. La acción médico-social contra el paludismo en la España metropolitana y colonial del siglo XX. Madrid: CSIC; 2003.

14. Granjel, n. 1, p. 155-159.

15. Vidal Jordana, Javier. La profilaxis del bocio endémico por el yodo y su aplicación en Las Hurdes. Archivos de Endocrinología y Nutrición. 1924; I (2): 65-71. 
from the region were not willing for photographs to be taken of their afflicted bodies and also resisted explorations of them. The report dedicated several pages to describing the geography and geology of the region, suggesting that endemic goiter was related to an isolated and poor environment, but also presented good results for iodine treatment of goiter in the region under his care. Playing his part in Marañón's socio-medical approach to endemic goiter in Las Hurdes, Vidal Jordana gave the impression that although the effects of iodine treatment were convincing, the region had a set of deficiencies, including communication, learning and nutrition that may have been having an effect on health conditions ${ }^{16}$.

Studies were also made in Barcelona of goiter and its prevalence in mountain regions such as the Montseny (a mountain range in Catalonia) and in some parts of the Pyrenees, led by professor of Physiology José María Bellido from the University of Barcelona Medical School in collaboration with two of his PhD students, J. Casimiro and J. Draper. They noted iodine deficiency as one factor involved but also considered some other «poorly defined» toxic factors ${ }^{17}$.

In 1935, Enrique Carrasco Cárdenas, a public health official and professor at the Escuela Nacional de Sanidad (School of Public Health, Madrid), published his pilot study for villages in Asturias (northern Spain) showing the effects of iodine on affected populations and urged the Public Health authorities to prevent it by iodine prophylaxis ${ }^{18}$. With an interest in diet and its deficiencies, in the 1920s, Carrasco Cadenas had previously examined diet in Madrid, its relation to public health and also to the protein and vitamin deficiencies that produced eye affections and problems in development as a social and healthcare problem ${ }^{19}$. Although there was information on the success of iodine treatment, there

16. Vidal Jordana, Javier. El bocio endémico en Las Hurdes. Archivos de Endocrinología y Nutrición. 1927; 5 (6): 245-266.

17. Works quoted in Cañadell, J. M; García-Valdecasas, Los síndromes bociosos experimentales y su relación con los clínicos. Medicina Clínica. 1946; 7: 44-53.

18. Carrasco Cadenas, Enrique. El bocio y cretinismo endémico como enfermedad por carencias alimenticias. Su profilaxis yódica. In: Temas de higiene alimentaria de urgente atención sanitaria. Tres conferencias. Madrid: Escuela Nacional de Sanidad; 1934, p 3-93. Carrasco Cadenas, Enrique. Estado actual de actividad del foco asturiano de bocio y cretinismo endémico: justificación de una campaña profiláctica. In: Congreso Nacional de Sanidad I. Madrid: Diana artes gráficas, 1934.

19. Del Cura, Isabel; Huertas, Rafael. Alimentación y enfermedad en tiempos de hambre: España, 1937-1947. Madrid: Consejo Superior de Investigaciones Científicas; 2007, p. 27-33. 
was no general agreement either on the origins or the treatment of thyroid disorders. Proposals differed regarding both diagnosis and treatment. The Royal Committee of Las Hurdes (Real Patronato) promoted new education programs and new roads were built to tackle the diagnosis of the problem of environmentally isolated underdevelopment.

The results of those studies of the effects of iodine on goitrous and cretinous patients did not lead to any general preventive campaign during the II Republic. Established in 1933, the II Spanish Republic remained in power in many regions of Spain up until the Civil War, when in October 1939, Franco's victorious army entered Madrid.

According to anthropologist Lellep Fernandez, the fact that Marañón did not support iodine prophylaxis may explain the delay in its adoption in Spain ${ }^{20}$. In defence of Marañón, it has also been argued that at the time it was difficult to accept such a single cause of a disease ${ }^{21}$. Castillo's historical review of goiter in Spain suggests that at that time not a single prophylaxis or treatment was known, even though the results obtained by Bayard in Switzerland with iodine had been considered extraordinary ${ }^{22}$. Granjel suggests that the then dominant toxic-infectious theory was in keeping with the ideas for social reform that such clinicians as Marañon proposed as solutions for the backwardness and marginalisation of Las Hurdes ${ }^{23}$.

As was the case with many other activities in Spanish public life before the Civil War, not only the discrepancies between clinicians but also the different views on the characterization of goiter may have been solved in favour of iodine prophylaxis had the Republic stayed in power and the Civil War not taken place ${ }^{24}$.

20. Fernández, Renate Lellep. A simple matter of salt. An ethnography of nutritional deficiency in Spain. Berkeley: University of California Press; 1990, p. 4-9 and p. 24-29.

21. Escobar; Morreale, n. 2.

22. Castillo Ortega, María Elena. Bocio y cretinismo en España: aproximación histórica [doctoral thesis].Madrid: Universidad Complutense de Madrid; 2002.

23. Granjel, n. 1, p. 155-159.

24. See Tortella, Gabriel. El desarrollo de la España contemporánea. Historia económica de los siglo XIX y XX. Madrid: Alianza; 1995. On social and public life: Cazorla, Antonio. Las políticas de la victoria. Madrid: Marcial Pons; 2000. At the universities, professors were purged for ideological reasons; see Claret, Jaume. El atroz desmoche. La destrucción de la universidad española por el franquismo, 1936-1945. Barcelona: Crítica; 2006. 
Dynamis 2009; 29: 337-363

\section{After the war}

As soon as professional life began to be reorganized after the Civil War, many health problems were subjected to renewed study. Some of these were published immediately after the war had ended, such as the one on the diet of Madrid's population during the war itself by expert nutritional clinician Francisco Grande Covian, and later on a longer study of diet during the early 1940s by Manuel Peráita and Grande himself ${ }^{25}$.

Studies of nutrition played a role in turning the authorities' attention back to iodine, as did the contribution made by clinicians with an interest in the subject or that had previously been involved in similar or related studies ${ }^{26}$. A review of hyperthyroidism published in 1945 introduced iodine, and reported that in hyperthyroidism, the thyroid has a huge need of iodine which cannot be solved by iodine, because it is systematically eliminated in these cases. The author mentioned works by J. Howard Means (Boston), Charles Leblond (Paris) and Joseph Hamilton (Berkeley) who used radioactive iodine to follow iodine in the body in order to show the metabolic trajectory of the element. The author also suggested that the accumulation of iodine in the thyroid gland contributed to a decrease in its size. Surgery and roentgen therapy showed the hyperfunction of the gland but the author had yet to find the solution to the problem ${ }^{27}$.

Iodine was gaining in popularity in the Spanish medical papers consulted. Slightly later, a review by one of the editors of the Barcelona medical journal Medicina Clinica together with a professor of Physiology at the University of Barcelona Medical School F. García Valdecasas mentioned in 1946 «the success of iodine prophylaxis» in the treatment of goiter and cretinism but they also pointed out that it did not completely suppress the disease. The clinical community, or at least some of its members, followed the literature on goiter published abroad in accordance with reviews published in Spanish clinical journals on papers and works by foreign medical researchers ${ }^{28}$.

25. Del Cura; Huertas, n. 19, p. 71-76.

26. Vilaclara, Juan M. Conceptos sobre patología funcional del hipertiroidismo con aplicación al diagnóstico y a la terapéutica. Medicina Clínica. 1945; 4: 377-383.

27. Arias Vallejo, Eduardo. El hipertiroidismo y su problema etiopatogénico. Medicina Clínica.1945; 4: 437-442.

28. Ferreiro Aláez, L; Escobar del Rey, F. 100 años de literatura sobre bocio endémico en España. Endocrinología. 1987; 34 (suppl. 2): 4-14. See, i. e., Laporte in Medicina Clínica. 1947; 8, p. 358-359 on the paper by Seidlin, Marinelly and Oshry. 
During this period the relation between goiter and iodine was the research subject of a group at the University of Granada Medical School (Granada, Spain). From 1946 on, Eduardo Ortiz de Landázuri, a young PhD MD trained under clinician Carlos Jiménez Díaz in Madrid, gained by public concourse a chair of Pathology ${ }^{29}$. He did research for his PhD on malnutrition as a disease, obtained his degree in 1944 in Madrid and by the late 1940s had created a Departmento de Fisiopatología de la Alimentación (physiopathology of food and nourishment) in Granada to perform research into endemic goiter in Las Alpujarras, a mountain region close to Granada. Ortiz de Landázuri is considered by his disciples to be the successor to Marañón as the leader of early endocrinology in Spain, precisely for his works on goiter, for creating the Sociedad Española de Endocrinología in 1950, a Spanish journal of endocrinology, Acta Endocrinológica Ibérica (19511952, Universidad de Granada, biblioteca) with the support of Marañón himself and for organising its first Spanish meeting on endocrinology, in Granada in $1954^{30}$.

It was there that he participated in more than thirty studies of endemic goiter in Las Alpujarras. By 1947 together with other collaborators he had established the need for water iodisation for goiter prevention and from then on iodisation became one of the main subjects of Ortiz de Landázuri's studies in Granada on the basis of the increasing number of successful cases. He contributed to public information about goiter and became one of the main supporters of iodine treatment. By drawing public attention to goiter both as a public health concern and as a research subject, he developed his own expertise. The fact he was a guest of the first Spanish meeting of endocrinology show his reputation among his peer physicians and medical researchers. In 1958 he was selected to set up a new school of medicine in Navarra (northern Spain) ${ }^{31}$.

29. Olagüe de Ros, Guillermo. La labor experimental del Laboratorio de Fisiología de la Nutrición (1947-1958) de la Cátedra de Patología General y Médica de Eduardo Ortiz de Landázuri. In: Martínez Pérez, José et al. eds. La medicina ante el nuevo milenio: una perspectiva histórica. Cuenca: Universidad de Castilla-La Mancha; 2004, p. 571-592.

30. Olagüe de Ros, n. 29.

31. Olagüe de Ros, n. 29. 


\section{4. «Good news» and new tools: radioiodine knowledge and practices}

It was the eventual provision of radioactive iodine that contributed to bringing attention back to iodine. Either as an element, or in its radioactive form, its relationship to thyroid disorders would be firmly emphasized. Reports on thyroid conditions and their treatments continued to be published in Spanish medical journals, as were articles on the potential for radioactive iodine as a useful element for both treatment and diagnosis. In 1945, early results for the use of radioactive iodine in animals were reported while surgery and $x$-radiation were considered among the means of firm diagnosis and proposals for treatment. However, the problems with the functions and disorders of the gland were still considered unsolved by some clinicians. For others, the results for iodine in the prophylaxis of anatomic and functional problems of the thyroid gland were clear ${ }^{32}$.

Goiter as a medical and public health problem crossed paths with the promotion of the use of radioisotopes, in this case iodine radioisotopes, to reinforce both research on iodine's role in the thyroid gland, and to promote the peaceful concept of their use. The physiopathology of iodine in thyroid disorders was investigated without losing sight of its medical and public health aspects. Throughout this process, knowledge of goiter became stabilized, and the public benefits of managing radioactive iodine were widely accepted.

According to a report published in 1948 by one of the editors of the Spanish journal Medicina Clinica, J. Vilar Bonet, the "good news" was that the US had made «a certain number of radioisotopes» available to researchers worldwide, which might be useful for clinicians and biologists ${ }^{33}$. «Isotope» was the term used to name forms of the same element that differed only in terms of their different atomic weights and the way they emitted different types of radiation without there being any difference in terms of their chemical properties, according to the report. Using available methods, almost every element could be «radioactivated»: as in the cyclotron, where particles with positive charges were accelerated in order to produce a radioactive element, i. e. by bombarding stable tellurium (Te-130) with deuterons, iodine 131 could be obtained. This isotope, said medical reporter Vilar Bonet, was a

32. Cañadell; García Valdecasas, n. 17

33. Vidal Bonet, J. Los isotopos en la investigación médica. Medicina Clínica. 1948; 10 (5): 337338. 
radioactive iodine that emits beta and gamma rays. Among its therapeutic applications was its use in the thyroid gland. Also the tracing of a given molecule (the author mentioned the likes of hormones, aminoacids, antibodies and antibiotics) would be of «considerable interest» in determining their metabolic processes.

In this report, Vidal Bonet informed about in vivo studies in which the Geiger counter made it possible to measure radioisotope concentrations in the body after their oral administration and to detect the absorption process. Detection of radioactive iodine in the thyroid gland was mentioned as one of the «best examples of the selective localization» of radioisotopes by these methods ${ }^{34}$. Papers published later helped reintroduce iodine as soon as radioactive iodine became available, suggesting that iodine had indeed become a powerful tool for explaining not only how the gland worked but also the extent to which its disorders were connected to iodine deficiency. Radioiodine is «avidly» absorbed by the thyroid gland, said the chronicler, who added that all these facts, and current knowledge on iodine metabolism, suggested its application was a valid therapy. «Once it is deposited iodine will emit radiations that may act therapeutically on the gland». The report also stated that during therapeutic application the same reactions were observed as those in radiotherapy, such as nausea and sickness, suggesting that it was precisely previous results with radiotherapy that supported the interest in radioisotopes ${ }^{35}$.

Radioiodine was the outstanding radioelement used in experimental medicine by 1948. It became a standard treatment for toxic goiter and was used by about 20 medical centers in the US. Although early research with iodine radioisotopes generated hope with regard to its effect in the treatment of cancer, practical uses pertained to the realm of diagnosis ${ }^{36}$. Results for radioiodine research began to be widely distributed and a corpus of the uses of these tools obtained in the cyclotron and from the atomic pile was already being made by $1948^{37}$.

\footnotetext{
34. On Geiger-Müller counter, see Kraft, n. 3, p. 10-13.

35. Pérez Vitoria, C. Las modernas terapéuticas médicas de la hiperfunción tiroidea. Medicina Clínica. 1949; 12: p. 200-206 (203).

36. Creager, 2006, n. 3, p. 668-669. Chapman, Earl M.; Evans, Robley D. The treatment of hypothyroidism with radioactive iodine. Journal of the American Medical Association. 1946; 131 (2): 86-91.

37. Among the earliest: Hamilton, Joseph. The use of tracers in biology and medicine. Radiology. 1942; 39: 541-572.
} 


\section{Requesting procedures: a US-Spain Agreement in 1949}

In 1946 an announcement from the Headquarters of the Manhattan Project in Washington DC distributed the news of the «Availability of Radioactive isotopes» ${ }^{38}$. This statement marked the launch of a campaign to recycle atomic energy in order to guarantee that atomic energy and its expert community would not be put in jeopardy by the destructive capacity of nuclear bombs, a successful event which also launched the adverse reactions of some researchers that were deeply concerned about the issue ${ }^{39}$.

One of the first requests from Spain received by the US Atomic Energy Commission Isotope Branch at Oak Ridge was that from Eduardo Sánchez Serrano, from the Laboratory of Radioactivity at the Instituto Nacional de Geofísica in May 1947. When he asked for information on the «export of radioactive material», he was interested in receiving the catalogue of isotopes, including the price list. However, the US AEC had only recently assumed control of the atomic energy facilities, and at that time the Commission was «considering» equitable international distribution, although it also required some time before such arrangements could be completed. Isotopes were not abundant at the time, and they were produced «primarily» in a research laboratory, according to the AEC's answer to Sánchez Serrano's request a week later ${ }^{40}$.

AEC bureaucracy appeared to be standing in the way of established procedures for processing requests, including priorities, the qualification of requesters and the adequacy of the facilities available to them. The requester had to arrange transportation as overseas trade was to be by air (because of the short half-life of isotopes) and air transportation of this kind of material was not allowed by airline companies. By June 1947 it had become «impossible» to predict a date when radioisotopes would be available for export, but the assistant who answered Sánchez Serrano's

38. Availability of radioactive isotopes. Science. 1946; 103: 697-705. See also Creager, 2002, n. 3; and Hewlett, Richard G.; Anderson, Oscar E. History of the United States Atomic Energy Commission. Vol 1, The New World, 1939/1946. Pennsylvania: The Pennsylvania State University Press; 1962.

39. Hewlett; Anderson, n. 38.

40. On Sánchez Serrano request see R- Instituto Nacional de Geofísica, Atomic Energy Commission, Manhattan Engineer District, Clinton Engineers Work, General Research Correspondence, Entry 004, Accession Number 67 A803, Box 173, File AEC 441.2 (hereafter US AEC archives, Instituto Nacional de Geofísica, 1947). 
request recommended that an official Spanish scientific organization, such a national academy of science, should initiate a formal request to the Commission to arrange for supplies ${ }^{41}$.

Around the same time, in March 1947, the Spanish Embassy in Washington received a request from Spain (no other information on the request or the requester was included) for radioactive iodine and a similar response to that sent to Sánchez Serrano was sent from Oak Ridge to the Military Attaché of the Spanish Embassy Lieutenant Colonel F. C. Camino. In August 1947, Camino repeated his request, but the conditions had not changed as the Isotopes Branch was not yet authorized to accept requests from foreign countries. In September 4, the Spanish attaché read President Truman's announcement in the New York Times on the «lifting of exportation of radioactive isotopes» and once again asked the Isotopes Branch to tell him what steps should be taken to obtain «some» ${ }^{42}$. In late September, Camino received copies of the catalogue and an outline of the procedure for handling international distribution of radioisotopes. In December, after a request from the AEC for a national representative for radioisotope distribution in Spain, the Spanish Embassy's deputy secretary was appointed the representative in the US to handle matters of radioisotope purchases ${ }^{43}$.

Radioisotope distribution outside the United States was a controversial affair due to the restrictive US security policy during the early Cold War years when isotopes began to be made ready for use by US researchers. According to Creager, at the time of the launch of the radioisotope distribution program, scientists were advocating the foreign distribution of radioisotopes as soon as they were available from the US Atomic Energy Commission, arguing that it was all about fostering science and having good relations with their colleagues in Western Europe. However, bureaucrats and politicians considered it more urgent to maintain national security controls. The debates may have continued, but foreign distribution was authorized by the fall of $1947^{44}$.

41. E. Sánchez Serrano to Paul Aebersold, May 23 1947; and Richard E. Fisk, assistant, to E. Sánchez Serrano, June 4 1947. US AEC archives, Instituto Nacional de Geofísica, 1947.

42. Camino to Aebersold, March 10 1947; Jones to Camino, March 14 1947; Camino to Jones, August 7 1947; Jones to Camino, August 14 1947; Camino to Jones, September 4 1947. Atomic Energy Commission Archives (AEC) 441.2 : R-Spain, Embassy of.

43. Baraibar, Charge d'Afaires, to Aebersold, December 18 1947. AEC 441.2. R-Spain, Embassy of.

44. Creager, 2002, n. 3. 
Late in January 1948, a letter was sent requesting radioisotopes by the Instituto Nacional de Geofísica in Madrid. The AEC Isotopes Division (not a Branch any longer) sent it back to the Spanish Embassy recommending it should be resubmitted by the official representative of Spain ${ }^{45}$. In addition to a catalogue, «Radioisotopes for international distribution», a circular E-7 «Procedure for handling foreign requests» was issued by the US AEC Isotopes Division in September 1947 and when the supply of these circulars «was exhausted» a re-edition was published in which both were included as part of the same booklet ${ }^{46}$. The catalogue included prices that were set in order to recover 60 per cent of production cost. Radioisotope production was much cheaper in the reactor than in the cyclotron but not all of them could be produced in the former. Prices were mainly subsidized because the AEC was supporting cancer research: from April 1948 the AEC distributed radioiodine free of production costs when it was for cancer research, diagnosis or therapy ${ }^{47}$.

After interchanges between the two parties in order for the right conditions to be met concerning the Spanish request for radioisotopes and for receipt of the same, the Spanish Embassy in Washington sent a two-page agreement to the Department of State in March 161948. The Department of State considered it as «satisfactory». It included the appointment of both the Secretary of the Spanish Embassy and the company Tracerlab Inc, Boston, as the representatives authorized to arrange radioisotope shipments from US AEC to Spain when requested ${ }^{48}$. As a private corporation, Tracerlab was one of the participants in the early industrialization of radioisotopes, which the US AEC promoted mostly by contracts for the management of nuclear research laboratories 49 . The Secretary of the Embassy and Tracerlab would certify on behalf of the Spanish Government the accuracy of the information included in each request. The agreement also included clarification of the hazards when possessing, handling and using radioisotopes and the insistence that certain measures should be taken in every case, and finally accepted

\footnotetext{
45. Jones to Baraibar, January 29 1948. AEC Archives 441.2. R-Spain, Embassy of.

46. Jones to Baraibar, March 3 1948; AEC Archives, 441.2. R-Spain, Embassy of.

47. Creager, 2004, n. 3, p. 152.

48. Spanish Embassy to Department of State, March 161948 (copy); AEC Archives 441.2. R-Spain, Embassy of.

49. Creager, 2004, n. 3.
} 
that nobody in the US, either a US agency, department or the government as such would be responsible for any damage related to isotope deliveries. After the written acceptation of this statement from the Embassy by the Department of State in March 1948, individual lots of isotopes began to be requested and catered for ${ }^{50}$.

This agreement, signed in March 1948, was the very first between the US through the State Department and Spain through its Embassy in Washington, and was apparently a commercial arrangement of scientific and medical significance and for scientific and medical purposes. At this time, after the constitution of the United Nations, Spain was diplomatically isolated since the UN assembly held in San Francisco (California) in June 1945 had refused membership of the organization to states whose regime was established with the support of military forces. The Spanish government was also mentioned at the Postdam Conference in July 1945 when Harry Truman, Josef Stalin and C.R. Atlee stated that it was impossible for Spain to be a member of the UN. The next UN conference in December 1946 not only passed a resolution against Spanish membership but also recommended that its members should withdraw their Ambassadors from Madrid. But despite that period of political isolation, commercial agreements were in force that made trade, private business and banking arrangements possible with allied countries ${ }^{51}$.

At that particular time, in March 1948, the US had also begun negotiations with Spain for the development of the basis for a further agreement that might involve Spain in Cold War political geography. Even though President Truman was explicitly against the Franco regime, some military considerations were at play. Because of Spain's strategic situation for

50. Department of State to the Charge of Affairs of the Spanish Embassy, Washington DC March 25 1948; AEC Archives 441.2. R-Spain, Embassy of.

51. Portero, Florentino. Franco aislado: la cuestion española (1945-1950). Madrid: Aguilar; 1989. Ordóñez, Javier; Sánchez Ron, José Manuel. Nuclear Energy in Spain: From Hiroshima to the sixties. In: Forman, Paul; Sánchez-Ron, José Manuel, eds. National military establishments and the advancement of science and technology. Dordrecht: Kluwer; 1996, p. 185-213, on p. 186-187. Romero, Ana; Sánchez Ron, José Manuel. Energía Nuclear en España: de la JEN al Ciemat. Madrid: Ciemat; 2001, p. 13-41. On Spanish exports and trade, see Guirao, Fernando. Spain and the reconstruction of Western Europe 1945-57. Londres: MacMillan; 1998. On the negotiations toward the 1953 agreement, see Viñas, Ángel. Los pactos secretos de Franco con los Estados Unidos. Bases, ayuda económica, recortes de soberanía. Barcelona: Grijalbo; 1981. Viñas, Angel et al. Política commercial exterior de España (1936-1975). Madrid: Fundación Banco Exterior; 1979. 
establishing military bases in case conflicts with the Soviet Union should occur, the US secretary of Defense believed in the convenience of recovering a relationship with Franco ${ }^{52}$. It was not until 1953 that Spain signed an agreement with the US that officially ended the diplomatic isolation of the Franco regime; although its contents were kept secret at the time. It was the beginning of the end of the international political isolation of the dictatorship, something that major Spanish diplomatic efforts in Washington had been working towards since the end of WWII ${ }^{53}$.

The radioisotope agreement might well have played a part in this environment of the growing political inclusion of Spain in Cold War politics, although it would be misleading to claim any direct influence of radioisotope practices and promises in diplomatic developments between the US and Spain. However, there was room for atomic energy to be involved in the diplomacy of this very time, and the radioisotope episode should be considered a part of it. ${ }^{54}$ Requests for radioisotopes from Spain were not an isolated issue, not even one that was isolated from the international politics regarding the Franco regime. At the same time, post-WWII policy toward the Spanish dictatorship was not a single compact item, but rather was composed of many items in which trade, and also scientific cooperation, were compatible with political isolation. However, the frontier between trade and politics is difficult to trace, but may be related to military defense interests, in this case atomic energy as a military force. Atomic energy as a scientific and medical issue might have been considered a civilian issue and one that in 1948 was not yet regarded by the Spanish authorities as having any relation to defense. This situation would eventually change by the signing of an agreement for peaceful uses of atomic energy in 1955, when the connections between weapons and peaceful uses were recognized in order to establish a border to keep them separated for the purposes of the agreement. The 1955 agreement promoted the inclusion of Spain in the development of experimental reactors for power production. Although uses in medicine and biology were also mentioned, the medical and research uses of radioisotopes were still in the background on a political level.

52. Portero, n. 51, p. 286-293.

53. See also Viñas, n. 51.

54. Krige, n. 6. 


\section{Circulating radioiodine}

Political isolation of the Franco regime notwithstanding, or even in spite of it, everything was ready for radioisotopes to be requested and received by Spain from the US by April 1948. At that time, not only had clinicians begun to offer information on the possibilities of radioactive uses in medicine and therapy, but chemists and physicists also reviewed the data available. Physicist Eduardo Sánchez Serrano, head of the Radiophysics section at the Instituto Nacional de Geof ísica of the CSIC (Consejo Superior de Investigaciones Científicas, National Council for Scientific Research) and one of the first, if not the very first, requesters of radioisotopes for Spain, had already published a long introductory paper on the use of radioisotopes as tracers, in which he reviewed their practical uses and criteria for deciding which to use and how to work with them. He «limited references to those that were more easily available and of more relevance for their special interest and momentum until April 1, 1948» ${ }^{55}$, Sánchez Serrano became a specialist in radioactive isotopes over subsequent years at the Instituto Nacional de Geofísica. During this period he started collaborating with clinicians in relation to the medical uses of radioisotopes.

By 1949 «benefits of atomic energy» were regarded among the «major developments in the atomic energy program» by the US Atomic Energy Commission. "Iodine 131 and sodium 24 radiate both beta particles and gamma rays - and it is these emissions which gave them their special value to science», stated an AEC report published that year. On pages that followed in the same report, this idea was developed: «Scientists have used radioiodine to treat people with an overactive thyroid gland (...) because the gland absorbs almost all the iodine taken into the body. They have used radioiodine similarly to trace out seats of new cancers that have spread from a thyroid root». Curative results remained the main promise ${ }^{56}$.

Four shipments of radioisotopes came to Spain from the US up until the end of 1950: a sample of C-14 in April 1948 was followed by one of I-131 sent to the University of Madrid in September 1949 for the treatment of thyroid carcinoma by Tracerlab, Boston. Also in September 1949, P-32 was

55. Sánchez Serrano, E. Uso de los isótopos como indicadores. Información de Química Analítica II. 1948; 4: 119-130 (119); and 1948; 5: 164-170.

56. U.S. AEC. Isotopes: A Three-Year Summary. Washington DC: U.S. Government Printing Office; 1949, p. 75,88 , and 89-90. 
sent to the «Department of Health, Madrid» for cancer therapy followed by a sample of Au-198 to the University of Madrid for cancer treatment ${ }^{57}$.

Radiology professor Carlos Gil y Gil of the University of Madrid Medical School may have been the recipient of the I-131 sample that was transshipped to the University of Madrid School of Medicine ${ }^{58}$. Gil y Gil visited the US in 1946 to learn about radiation and cancer on a grant from the Spanish Ministry of Foreign Affairs agency for Cultural Relationships ${ }^{59}$. At that time, training in the recent treatment of cancers was the basis upon which some other grants were awarded to Spanish physicians visiting the US after WWII, when the study of cancer was among the lines of medical research that received the support of the US AEC Radioisotopes Program ${ }^{60}$.

Gil y Gil was also the head of a Section for Radiology at the Consejo Superior de Investigaciones Científicas (CSIC), in Madrid ${ }^{61}$. In 1943 he created the San Francisco Javier Clinic of Physical Medicine and later on, in 1946, he participated in the Sociedad Española de Electrología y Radiología Médicas. His interests in radioisotopes might have originated from the associations between radiology and cancer treatment, the issue of his discourse for entry into the Spanish National Academy of Medicine in 1946, with further developments in radioisotopes for cancer. From the early 1950s, Gil y Gil organized seminars on «Radioisotopes» from his chair at the Medical School in Madrid while continuing his duties as an x-ray radiologist. In 1952 he was the Spanish representative at the International Congress of Physics Therapeutics for the general subject of «Radioisotopes», which suggests recognition of his expertise by the academic authorities in Spain at that time. He was well known in Spain in this period as a result of his work as a radiologist ${ }^{62}$.

Early clinical users of I-131 included Carlos Blanco Soler, chief of the Nutrition and General Medicine Department at the Hospital de la Cruz Roja, Madrid, who developed diagnostic procedures using I 131 in the early

57. Reports of foreign shipments of radioisotopes [vol. 3]; Record Group 326, EG7A, Box 47, Folder 4, AEC Records, US National Archives.

58. Castell, Manuel. Historia de la medicina nuclear en España. Barcelona: CETIR; 1993. Castell's dates of the shipments and origin of the sample coincides with that of NARA archives.

59. «Carlos Gil y Gil»; Archivo General de la Administración (Alcalá de Henares, Madrid), Ministerio de Asuntos Exteriores, Junta de Relaciones Culturales, 102601 54/8479.

60. On radioisotopes from Harwell, see Herrán, this issue.

61. Memoria CSIC, 1958.

62. Libro-Homenaje al doctor Carlos Gil y Gil. Madrid: C.I.O.; 1967. 
1950s. He worked mainly with I-131 but also with P-32 and radioactive cobalt. His group received radioisotopes from the British Atomic Energy Agency ${ }^{63}$. Iodine seemed to be related to his duties and expertise in nutrition. According to his records, he and J. Otte and certain other collaborators at the Hospital de la Cruz Roja in Madrid were among the first Spaniards to use I-131 for the treatment of hyperthyroidism ${ }^{64}$.

Having graduated in Medicine in 1916, Blanco Soler obtained his PhD in 1917 and worked as a clinician for the Cuerpo de la Beneficiencia Municipal (Health Department of Madrid). He was a renowned endocrinologist and geriatrician, who also specialized in diabetes and combined his activity as a private physician in Madrid with his clinical work in medical assistance at the Red Cross hospital and teaching at the School of Health (Escuela de Sanidad) ${ }^{65}$. In this clinical setting he created a Unit of Radioactive Isotopes, of which he was the director. He was also known for his work as a writer, having authored many books on aging, and on famous historical Spaniards such as the Duchess of Alba, and Don Juan ${ }^{66}$.

Blanco Soler's texts on radioisotopes, written with his collaborators at the Red Cross Hospital (Hospital de la Cruz Roja San José y Santa Adela), José W. Otte and Eduardo Sánchez Serrano, were based on the courses they gave at the Hospital from 1950 onwards, and specialized in endocrinology issues. A defender of the therapeutic use of iodine in thyroid disorders, he stressed the interesting results for the use of I-131 in endocrinology, mostly in diagnosis. He noted the usefulness of radioactive isotope of iodine I-131 in the treatment of goiter but also that its use in therapy, and also in cancer, had become by 1951 more of a promise than a reality, as it was of greater importance in studies of «biological physiology» ${ }^{67}$.

In 1953, the emphasis on radioisotope use was put into diagnosis. In a book for non-expert readers, US physicist Ralph E. Lapp dedicated some pages to radioiodine and its possibilities: «A patient could swallow a radioiodine

63. Blanco-Soler, C. Tratamiento del cáncer con isótopos radiactivos. Medicina Clínica. 1952; 18: 393-400.

64. Blanco-Soler, n. 63, p. 396. Escobar; Morreale, n. 2; and Castell, n. 58 mentioned Blanco-Soler among the first Spanish experts on I-131.

65. See Matilla, Valentín. Carlos Blanco Soler. In: Matilla, Valentín. 202 biografías académicas. Madrid: Real Academia Nacional de Medicina; 1987, p. 287-289.

66. En memoria del Excmo. Sr. D. Carlos Blanco Soler. Anales de la Real Academia Nacional de Medicina. 1962; 79: 485-502.

67. Blanco Soler, Carlos. Los isótopos en medicina. Madrid: Bermejo; 1951, p. 37-38. 
solution, popularly called an atomic cocktail, and then the rate at which his thyroid picked up radioactivity was a measure of the functional state of the gland». Swallowing also made «internal therapy» effective as radioiodine «selectively deposited in the thyroid, was a solution which allows rays to bombard only the thyroid and very few other tissues» ${ }^{6}$.

At the CSIC in Madrid a Sección (Unit) de Radioisótopos was set up in 1955. Physician Severino Perez Modrego was appointed head of the unit. A research fellow of the CSIC, his early research after graduation in 1945 was dedicated to cancer. As a postdoctoral student in England, on a fellowship of the Royal Society of Medicine, Pérez Modrego trained in nuclear medicine. As a Spanish representative, he visited US clinical settings where nuclear energy was being used for medical purposes. Pérez Modrego did research into radioisotope techniques, both with P-32 (treatment of polycythemia vera) and I-131 (thyroid pathology) ${ }^{69}$. Like Blanco Soler, Pérez Modrego participated in the Sociedad Española de Electrología, Radiología y Medicina Nuclear as an advisor on nuclear medicine, and in 1956 was appointed head of a new radioactive isotopes unit at the Instituto de Patología Médica, directed by Marañón ${ }^{70}$.

In January 1955 the Spanish authority for atomic issues, the Junta de Energía Nuclear (JEN, National Council for Nuclear Energy) created a committee to coordinate and control the use and effects of radioactivity in biology and medicine. Within its management structure, a Committee on Medicine and Animal Biology was set up to advise authorities on the use of radioisotopes and radiations. The aforementioned clinicians were to be members of the Committee: Carlos Gil y Gil and Severino Pérez-Modrego together with some distinguished clinicians and medical researchers including Gregorio Marañón, Carlos Jiménez Díaz and Julián Sanz Ibáñez together with radiochemistry expert J. Miguel Gamboa ${ }^{71}$.

In July 1955 the aforementioned agreement between the US government and the Spanish government for the peaceful uses of atomic energy was

68. Lapp, Ralph E. The new force: The story of atoms and people. New York: Harper \& Brothers; 1953, p. 188-189.

69. El átomo y sus aplicaciones pacíficas. Madrid: Sindicato Nacional de Agua, Gas y Electricidad; 1958, p. 127-128; and p. 129-131. Also Colaboradores e Investigadores del Consejo Superior de Investigaciones Científicas. Madrid: CSIC; 1957.

70. Castell, n. 58, p. 35.

71. Romero; Sánchez Ron, n. 51, p.95-96. 
signed ${ }^{72}$. In 1957 a radioisotopes department was established at the JEN in Madrid to produce radioisotopes. There were still technical constraints, mainly the deficient functioning of the experimental nuclear reactors, and radioisotope imports increased ${ }^{73}$.

As occurred earlier in the US, medical uses of radioisotopes came before any effort toward producing electrical power from nuclear energy. It was six years before Spain joined the Atoms for Peace campaign whereupon the Spanish government committed itself to supporting requests for radioisotopes for use in biology and medicine. Atomic pharmacies mentioned in a Madrid daily in 1950 preceded any project for an experimental reactor for any Spanish institute or corporate firm ${ }^{74}$. Uses of radioisotopes in biology and medicine were not an application of atomic energy but one of its earliest promoters.

Books and papers published in foreign and Spanish medical journals on the uses of radioactive iodine helped promote the study of iodine and interest in the relationship between thyroid disorders and iodine. The influence of pre-war interests in iodine and studies of its action found continuity in endocrinology, through the direct influence of Gregorio Marañón, as in the case of Pérez Modrego. In being traceable into the thyroid gland, radioiodine's reinforced the role played by iodine knowledge and practices related to the functions and disorders of these glands and their hormones. The epistemic role of iodine was strengthened by the introduction of a new material and its associated culture to experimental and clinical medicine.

\section{A laboratory of experimental endocrinology}

The careers of the research partnership of Gabriela Morreale, a chemistry graduate, and Francisco Escobar, a medicine graduate, share part of the genealogy of iodine ${ }^{75}$. After being members of the group led by Ortiz de

72. Agreement for cooperation between the government of the United States of America and the government of Spain concerning civil uses of atomic energy. In: United States treaties and other international agreements, vol. 6, part 2, Washington, D.C.: Government Printing Office; 1955, p. 2689-2694.

73. Romero; Sánchez Ron, n. 51, p. 132-135.

74. «Farmacias atómicas», Pueblo (Madrid daily). In Castell, n. 58, p. 21.

75. This section is a short version of one included in Santesmases, n.3, p. 776-782. 
Landázuri in Granada in the early 1940s, where they had worked on the relationship between goiter and iodine, Morreale and Escobar went on to Leiden (the Netherlands) to become experts in the uses and handling of radioiodine. While in Granada, Morreale had been able to measure stable iodine concentrations as part of the project on endemic goiter ${ }^{76}$. In Leiden, under the supervision of Andreis Querido, they began to work with radioiodine.

Querido was a professor of internal medicine at the University of Leiden and was also in charge of endocrinology and metabolic diseases. In the late 1940s he had worked as a Rockefeller Foundation fellow at the Thyroid Unit at the Massachusetts General Hospital (Boston), where he first started researching thyroids. John B. Stanbury, from the Thyroid Clinic at the Massachusetts General Hospital, where he had met Querido while working in Mean's group, spent a sabbatical with him in Leiden. This is how a line originating directly from the Bostonian pioneers of radioiodine in the thyroid came into contact with two Spanish biomedical researchers who were investigating ways of using radioiodine in their research into the physiology of the thyroid gland ${ }^{77}$.

By the time Morreale and Escobar had gone to Leiden, radioiodine had become a common tool in diagnosis and clinical therapy. The patient took it orally and gland radioactivity for different times was determined by an external counter. Practices of radioiodine determination included the concentration of iodine for diagnostic purposes: a normal gland showed increasing radioactivity for the first 24 hours, which then began to decrease. Hyperthyroidism was detected when the radioactivity increased at a much faster rate. Iodine concentrations in the blood were measured at different times by the precipitation of blood-serum protein bounded to it. The lower the hypothyroidism maximal values of radioactivity, the slower the release and the lower the amount of iodine bounded to blood serum. By diagnosis procedures, therapeutic doses of radioactive iodine

76. See, among others, Ortiz de Landázuri, E., Morreale, G., Escobar, F., Mora Lara, J. R. Valor clínico de la iodemia en las alteraciones del tiroides. Revista Clínica Española. 1954; 55: 235-243.

77. Morreale, Gabriela; Escobar, Francisco. La endocrinología experimental en España y el yodo readiactivo. In: Santesmases, M. J., and Romero, A., eds. La física y las ciencias de la vida en el siglo XX: radiactividad y biología. Madrid: UAM-CSN; 2003, p. 89-101. Stanbury, John B; Morreale, Gabriela; Escobar, Francisco. Andries Querido, obituary note. IDD Newsletter. 2001; 17 (2): p. 31-32. Accesible at http://www.iccidd.org/media/IDD\%20Newsletter/1991-2006/ v17n2_0501_4c.pdf [accessed December 15, 2008]. 
were also determined and in some cases a certain part of the gland was extracted by surgery ${ }^{78}$.

Those radioiodine practices were also used by Morreale and Escobar in their study of the adaptation processes observed in conditions of iodine deficiency. Stanbury himself made a study of endemic goiter in relation to iodine nutrition in Mendoza, Argentina, in the early 1950s along with a group of local physicians ${ }^{79}$.

Back in Spain, in 1958, Escobar and Morreale created a new laboratory in Madrid that had very basic technical facilities, but which was considerably improved by the support received from the Atomic Energy Agency in 1961 for three years. They used what had by then become a common procedure: the use of traced thyroxin - radioiodine thyroid hormone - in experimental animals in order to follow its entire path through body tissues. After sacrificing the animals, the tissue extracts, blood and serum, urine and excreta provided samples in which radioactivity was measured as a sign of iodine concentration. Using related methods, they studied the inhibition of thyroid hormone synthesis. Later on, they introduced radioimmunoassay to show the need for iodine consumption during pregnancy by establishing a relationship between maternal thyroid hormones and fetus brain development ${ }^{80}$.

Apart from their contribution to experimental endocrinology, Morreale and Escobar remained supporters of iodine prophylaxis for goiter prevention and became defenders of salt iodisation. Their active participation in the issue of goiter as a public health concern included not only academic research but also participation in the creation of the International Council for the Control of Iodine Deficiency Disorders (ICCIDD) in 1985. This organization promotes the need for research and education on the consequences of iodine deficiency and its prophylaxis by consumption of iodized salts ${ }^{81}$. Directly from a Spanish laboratory engaged in the study of the relationship between

\footnotetext{
78. Morreale; Escobar, n. 2.

79. Stanbury, John B.; Brownell, Gordon Lee; Perinetti, Héctor; Riggs, Douglas S. Endemic goiter. The adaptation of man to iodine deficiency. Cambridge, MA: Harvard University Press; 1954. See also Stanbury, John B. lodine deficiency and related issues: a personal historical account. IDD Newsletter. 1999; 15(4). Avalaible at http://www.iccidd.org/media/IDD\%20Newsletter/19912006/nov1999.htm\#a3 [accessed December 15, 2008].

80. Escobar del Rey, F.; Morreale de Escobar, G. The effect of propylthiouracil, methylthiouracil and thiouracil on the peripheral metabolism of I-thyroxine in thyroidectomized, I-thyroxine maintained rats. Endocrinology. 1961; 69: 456-465.

81. See ICCIDD webpage at http://www.iccidd.org/ [accessed December 15, 2008].
} 
iodine and goiter, they included a new tool and its associated techniques in their research agenda and used it to expand upon their work on the role of iodine in the thyroid gland.

\section{Conclusions: for a history of iodine}

The trajectory of iodine shows the paths taken by an element that from the early $20^{\text {th }}$ century was known to be related to goiter. This endemic produced unhealthy and diseased populations in isolated regions. When this isolation began to be in part overcome by developments in communications (roads as well as iodine therapy) war put a halt to the tendency in Spain towards a better understanding of the treatment of goiter. Goiter was known by then to be a thyroid gland disorder, the main anatomic sign of which was the prominent swelling of the neck. During the Spanish Civil War, new results were found in the US after radioiodine had been used in experimental medicine and biological research by certain research groups that were in contact with physicists involved in nuclear reactor construction projects. It was then that the use of stable iodine shifted towards its radioactive isotopes, and this shift made its presence in the gland and in extracted samples visible and detectable. The capacity for detection was one of the main arguments for producing radioiodine for experimental purposes. The Geiger-Müller counter played a role in this visualization of iodine in living bodies.

At first only a by-product of uranium fission in cyclotrons, radioiodine was used as a captivating tool in medicine, together with its envisaged therapeutic effects inspired by the results that had previously been obtained with $\mathrm{X}$-ray therapy. After contributing to legitimate nuclear physics projects in the 1930s, during the war medical interest in radioiodine also developed as part of the Manhattan project. From the end of WWII, after atomic bombs had been dropped on Hiroshima and Nagasaki, iodine was recovered, as were other radioisotopes that had previously been used in biological and medical research, as part of strategies aimed at keeping nuclear research on the US authorities' scientific program for the Cold War years.

As Angela Creager has pointed out, the Atomic Energy Commission's radioisotope distribution program, despite being based on research results obtained before WWII, changed the scale of both production and use, and by the late 1940s they had become widely available to Western scientists. 
By then, the UK Atomic Energy Agency had become the main supplier to the European continent. Throughout this process, goiter came across radioiodine in medical research and clinical practices regarding treatment of the thyroid gland's functions and disorders ${ }^{82}$. Diagnosis of these disorders and prospective therapies considerably developed in parallel with the availability of radioiodine and later of radioactive labeled molecules (in this case, thyroid hormones).

There had been no time to discuss and implement any general health policy for the prevention and treatment of goiter by administration of iodine to the affected population before the Spanish Civil War (1936-1939). In its aftermath, and when WWII was also over, goiter recovered its agency in Spain, in research and medicine through experimental endocrinology, associated to the nutritional problems that had arisen in the midst of the food shortages of the 1940s. Spanish clinicians were informed of the earliest results with this atomic tool, and the so-called atomic cocktail participated in experiments that explored the connection between iodine deficiency and goiter. Being a powerful tool that made iodine visible in vivo and in vitro, it helped put iodine, in its radioactive form or not, at the core of explanations of thyroid disorders.

The circulation of iodine knowledge and practices, along with transshipments of the element from Oak Ridge or Boston to Madrid for medical treatment and experimental endocrinology in local settings, stabilized goiter as iodine deficiency while also stabilizing radioiodine as a central tool in the development of nuclear medicine. Some clinicians, chemists and physicists took part in the early diagnosis and experimental therapies, including those mentioned above who requested and received the earliest samples of I-131 in Spain.

The earliest agreement between the US and Spain to satisfy Spanish requests for radioisotopes was signed in 1948, before the establishment of diplomatic relations between the two countries, which did not take place until 1953. These scientific and political developments involving the Spanish Embassy in Washington meant that radioisotopes became not only an agent of scientific cooperation and trade but also of diplomacy. By then, the international relations between scientists and clinicians that had been initiated in the previous decade, the harshest of the Franco regime, 
began to be recovered. As was the case with their role in the development of atomic energy itself, radioisotopes were at the very origin of a whole set of political and epistemic arenas of knowledge and practices that involved laboratory techniques and the reconstruction of diplomacy. This suggests the cultural embeddedness of atomic energy in contemporary history, and of contemporary political history in the development of techniques and experimental knowledge that eventually became clinical ${ }^{83}$.

Radioiodine created expert knowledge and clinical practices by becoming an instrumental element in thyroid gland related diagnosis. By making both diagnosis and treatment of the thyroid gland and its disorders visible, endocrinologic knowledge and practices developed in clinical settings in Madrid. It became associated to the stabilization of knowledge of goiter as a deficiency in iodine. The atomic cocktail remained for diagnosis uses, as did iodine as a treatment and prevention of goiter. The history of iodine from the 1920s to the 1960s crossed that of goiter. Samples of radioiodine and the practices and knowledge associated with it circulated and took part in the civilization of atomic energy as a result of its medical uses.

\section{Acknowledgements}

I wish to thank Angela Creager, Rafael Huertas, Alfredo Menéndez, Esteban Rodríguez-Ocaña and the anonymous referees from Dynamis for their comments on a previous version. I thank Gabriela Morreale and Francisco Escobar for providing information, Angela Creager for bringing my attention to archive material on Spain in the Atomic Energy Commission archives in Morrow (Georgia, USA), where Richard Rayburn kindly attended to my requests, and also the archivists at the Archivo General de la Administración in Alcalá de Henares (Madrid).

83. Doel, Ronald E. Scientists as policymakers, advisors, and intelligence agents: Linking contemporary diplomatic history with the history of contemporary science. In: Söderqvist, Thomas, ed. The Historiography of Contemporary Science and Technology. Amsterdam: Harwood; 1997, p. 215-244. 